\title{
Investment to Technologies Strengths and Weaknesses: Lithuania in the Context of EU
}

\author{
Ruta Adlyte, Loreta Valanciene, and Rytis Krusinskas
}

\begin{abstract}
This investigation was performed in order to find the main strengths and weaknesses of investment to technologies in Lithuanian case. The overview of literature complaining investment to technologies issues was made and the knowledge based economy was selected as the theoretical background for this investigation. Different investigations regarding investment to innovations were also reviewed and on the base of these investigations, the methodology for the investment to technologies evaluation was created. The summarized Investment to Technologies Index (ITI) was developed and Lithuania was assessed in the context of other European Union countries in the respect of three different perspectives: Skills and knowledge, Financial Investment and Technological Output. The investigation has shown Lithuanian potential and also week spheres that must be developed in order to reach the goals of Lithuanian Innovation Strategy 2010-2020.
\end{abstract}

Index Terms-Investment to technologies indicators, competitiveness, innovation strategy.

\section{INTRODUCTION}

Nowadays investment to technologies plays critical role for the development of every country: the economic growth, as well as living conditions and competitiveness of a country. Technologies and industrial innovations are supposed to be the main economical, ecological, and social wellness factor. They promote increase of living standard and increase of workforce productivity in governmental and private sector; they have impact on creation of new workplaces and new work spheres and on improvement of services; they promote competitiveness of the national production on the world [1].

Europe 2020 strategy put forward that there are three mutual reinforcing priorities [2]: 1) smart growth; 2) sustainable growth; 3) inclusive growth. This requires improving quality of education, knowledge transfer, making full use of communication technologies, investing to skills, new processes and technologies. According to [3] education and entrepreneurship have a critical role to play in maintaining and further enhancing Europe position as a key global player in upcoming years.

In Lithuanian case it is to notice that recent business conditions are not satisfying. In 2010 Lithuanian government adopted resolution regarding implementation of innovation strategy 2010-2020 of the Republic of Lithuania. The aim of this strategy-concentrate and to effectively manage country's

Manuscript received November 5, 2013; revised January 16, 2104. This research was funded by a grant (No. IEP-01/2012) from the Research Council of Lithuania.

The authors are with the Kaunas University of Technology, Lithuania (e-mail: ruta.adlyte@ktu.lt, loreta.valanciene@ktu.lt, rytis.krusinskas@ktu.lt). resources for the creation of competitive knowledge - based economy which is based on implementation of new technologies and availability of high qualified human resources [4]. In the Strategy a big attention is paid to the development of the High - Tech sector, which in turn, will increase the competitiveness of companies in the local and global markets through new products, new technologies, processes, business models and organization structures.

In the theoretical part of this paper the impact of technologies on the development of country's economy was analyzed within a scope of different theories: neoclassical [5], endogenous [6]-[8], evolutionary [9], knowledge - based economy [10] and others. In the methodological part different methods and overviews [11] evaluating innovations in the world and Europe were discussed and the system of indexes for the evaluation of investment to technologies was developed.

The main objective of this investigation was to evaluate Lithuania according to investments to technologies criteria in the context of European countries. This evaluation enables identification of the main strengths and weaknesses in the country and could work as a tool for adequate country's strategic proposals.

\section{THEORETICAL BACKGROUND}

The impact of technological progress to the economy growth was emphasized in well-known economic theories developed in the last century. However it had different approaches.

R. Solow created Neoclassical Growth model evaluating how the current level of the capital labor ratio and two parameters: the savings rate and the rate of population growth, determine the rate of change of the capital labor ratio [5]. However the model assumes that the economy growth is solely determined by exogenous technological progress whose rate is defined by scientific process which is independent of economic forces and not affected by short-term economic policies. Neoclassical theory does not provide interpretation of economic forces and strategies that influence main sources of long-run economic growth [12].

The Endogenous growth theory is based on the idea that technological progress is not simply determined by exogenous factors but is "produced" by innovation activities, including R\&D [7], [13]. Long-term growth is emanating from economic activities which create new technological knowledge.

A big attitude is paid to the intellectual capital in the Innovation-based endogenous growth theory. P. Romer developed one branch of this theory while emphasizing the 
importance of knowledge to the economic growth of the country. The other branch of innovation-based growth theory is the Schumpeterian" theory [6] developed by P. Aghion and P. Howitt [8], [14], [15] R\&D activities in this innovation - based theory are a driving horse of the economy growth. The way to grow rapidly is to devote a large fraction of output to R\&D, which has direct impact on workforce productivity. According to A.P. Bartel [16] progressiv industry branches are tending to pay more attention to education and training of workers and to invest more in this field as compared to the industry branches that are far behind regarding the implementation of technological advances.

The first formalized evolutionary model of growth which was proposed by R. Nelson and S. Winter [17] was based on theories of A. Marshal [18] and J.E. Schumpeter [6]. Within Nelson-Winter models a successful technological innovation generates profits for the firm making it, and leads to capital formation and growth of the firm. Firm growth generally is sufficient to outweigh any decline in employment per unit of output associated with productivity growth, and hence results in an increase in the demand for labor, which pulls up the real wage rate. This implies the growth of capital using but labor saving innovation profitability. As labor productivity, real wages, and capital intensity are rising, the same mechanisms regulate decrease of the return rate to capital. Creation of new productive technologies rise the profit rate, which will induce an investment boom, which in turn will pull up wages, and drive capital returns back down [19].

Knowledge based economy. Key instruments of knowledge based economy are new scientific knowledge, advanced information technologies and innovations. Radical implementation of innovations leads to the development of new technological processes and creation of new products. Continuous development of knowledge economy and investment in R\&D measures are prerequisite for securing of competitiveness on all levels. Governmental policy may accelerate the economy growth rate in the country creating conditions for free market competition and for implementation of $\mathrm{R} \& \mathrm{D}$ (innovation) products in the market. It was also recognized, that private investment in $R \& D$ is the most important engine of technological progress [20], [21], [22]. Investments in knowledge can increase the productive capacity of the other factors of production as well as transform them into new products and processes.

As knowledge based economy fits our investigation aims best, it was used as theoretical background in the present investigation to evaluate the impact of investment to technologies on the development of national economy, taking into account the complexity of economy system and indicators describing this system.

\section{CurRent RESEARCH OVERVIEW}

There are many systems of indicators and methodologies how to compare countries while speaking about knowledge and innovations.

World Bank calculates Knowledge Economy Index (KEI) that represents countries ability to compete in knowledge economy. Knowledge Economy Index is comprised of Economic Incentive and Institutional Regime Index (EIR) and Knowledge Index (KI). KEI is constructed of three indicators: Tariff \& Nontariff Barriers, Regulatory Quality, Rule of Law. The Economic Incentive and Institutional Regime index comprises incentives that promote the efficient use of existing and new knowledge and encourage entrepreneurship. Knowledge Index is constructed of three sub-indexes: 1) Innovation and Technological Adoption; 2) Education and Training and 3) Information and Communications Technologies (ICT) Infrastructure. According to the World Bank's Knowledge Assessment Methodology [23] the growth of global knowledge, its adoption to local needs and new technological solutions are influenced by an efficient innovation system made by firms, research centers, universities, and other organizations. Education and training are important for the community to create, use and share the knowledge. The effective communication and information processing could be performed only in the respect of modern and accessible information and communications technologies. According to [24], the Knowledge Index and Knowledge Economy Index help to identify the economic and social trends and transformations in the EU for the development of the processes highlighted by the comparative analysis. It gives researchers the opportunity to assess key indicators of values and changes in the economic and social development.

The opportunities for creation, adopting and export of technologies are highly related to firms' performance results. Firms performing in different counties have not the same conditions for their business. Economic freedom plays an important role here. Index of Economic Freedom is constructed of 10 different equally weighted components and assesses the situation in four perspectives [25]: 1) Rule of law (property rights, freedom from corruption); 2) Limited government (fiscal freedom, government spending); 3) Regulatory efficiency (business freedom, labor freedom, monetary freedom); 4) Open markets (trade freedom, investment freedom, financial freedom). Countries with higher level of economic freedom substantially outperform others in economic growth, per capita incomes, health care, education, environmental protection, and reduction of poverty.

Countries, having efficient innovation systems percept better, the importance of education, knowledge and new technologies.

Every year the European Commission publishes the Innovation Union Scoreboard providing a comparative assessment of the research and innovations in the $27 \mathrm{EU}$ Member States and Croatia (entered EU in 2013), Serbia, Macedonia, Turkey, Iceland, Norway and Switzerland and indicating relative strengths and weaknesses of each country. The assessment is based on the analysis of 25 indicators of 3 different types that cover 8 innovation dimensions [26]. First type of indicators are "Enablers" that capture the main drivers of innovation performance external to the firm and cover 3 innovation dimensions: Human resources (new doctorate graduates, population aged 30-34 with tertiary education, youth with at least upper secondary education): Open, excellent and attractive research systems (international scientific co-publications, top $10 \%$ most cited scientific publications, non- EU doctorate students) as well as 
Finance and support (R\&D expenditure in the public sector, venture capital investments).

"Firm activities" are second type of indicators that reflect the innovation efforts at the level of the firm, and are grouped in 3 innovation dimensions: Firm investments (R\&D expenditure in the business sector, non-R\&D innovation expenditure), Linkages \& entrepreneurship (SMEs innovating in-house, innovative SMEs collaborating with others, public-private co-publications) and Intellectual assets (PCT patent applications, PCT patent applications in societal challenges, community trademarks, Community designs).

Third type of indicators "Outputs" cover the effects of firms' innovation activities in 2 innovation dimensions: Innovators (SMEs with product or process innovations, SMEs with marketing or organizational innovations, high-growth innovative firms) and Economic effects (employment in knowledge intensive activities, MHT contribution to the trade balance, knowledge intensive services exports, sales of new to market and new to firm innovations, licenses and patent revenues from abroad).

To enable comparative analysis of innovation performance in different countries relative, scores for all years are re-scaled and a Composite Summary Innovation Index is calculated as the unweighted average of the re-scaled scores for all indicators. According to their average innovation performance, countries are assigned to four performance groups: the 'Innovation leaders', the 'Innovation followers', the 'Moderate innovators' and the 'Modest innovators' Tracking of progress in actual innovation performance within and outside the EU (EC: Innovation Union Scoreboard) over time is an important and supportive measure for national and EU economies considering implementation of correcting actions [26].

Another powerful tool for analyzing tendencies of innovation performance in different countries is Innobarometer (part of Eurobarometer) [11], which conducts an annual opinion poll of businesses or general public on attitudes and activities related to innovation policy and provides policy relevant information direct from business or the general public which is not available from other sources. Most recent EC co-ordinated surveys were related to economic assets and innovation drivers for growth [27], innovation in public sector [28], strategic trends of innovation [29], innovation transfer [30] and cluster's role in facilitating innovation [31].

Science and Technology indicators build a separate group and are used in Eurostat as well as in World Bank's statistic databases. However each database maintains different number of indicators. World bank uses such indicators as: Charges of the use of intellectual property, High-technology exports, Patent applications, Research and development expenditure, Scientific and technical journal articles, Technicians in R\&D, Trademark applications to describe progress of science and technologies, while Eurostat group's Science and Technologies indicators are: R\&D composed of Statistics on research and development and Government budget appropriations or outlays on R\&D, High-tech industry and knowledge-intensive services, Patent statistics, Human resources in Science and Technology. Eurostat also provides the results of EC innovation survey that investigates the innovation activity of the European enterprises.

The main principles of the investigations mentioned in this chapter were developed for the methodology of this evaluation for investment to technologies assessment and comparison between Europe countries.

\section{Methodology}

Following and adjusting methodology for index calculation described in Innovation Union Scoreboard and methodology for grouping of science and technology indicators (Eurostat) also taking into account investigations performed by other authors [32]-[36], model for calculation of the Investment to Technologies Index (ITI) was proposed, where ITI is defined as a function (1):

$$
(I T I)=f(S K, F I, T O)
$$

where $S K$ is Skills and Knowledge index, FI - Financial Investment index, $T O$ - Technological Output index

The selected indicators representing all three dimensions are: $X 1$-New doctorate graduates per 1000 population aged 25-34, X2 - Percentage population aged 30-34 having completed tertiary education, $X 3$ - Percentage youth aged 20-24 having attained at least upper secondary level education, X4- International scientific co-publications per million population - representing Skills and Knowledge; $X 5$ Public R\&D expenditures as \% of GDP, $X 6$ - Business R\&D expenditures as \% of GDP - Representing Financial Investment; $X 7$ - Number of enterprises in high-technology sectors, $X 8$ - high-tech patent applications to the EPO by priority year at the national level per million inhabitants, $X 9$ high tech exports as \% of all exports - representing Technological Output.

Each of the dimensions: $S K, F I, T O$, was calculated as unweighted average of the indicators defining these indexes. And finally, investment to technologies index (ITI) was calculated as the sum of $S K, F I$ and $T O$.

While comparing countries to each other, it is important to select countries having more or less similar performance conditions. All 28 European Union countries were chosen for comparison and evaluation of Lithuania's position, as they represent the same Union, are in the same geographical region, and are supposed to have more likely similar positions than while comparing with other counties of the World.

The analysis began with 2001 year and following the methodology of Innovation Union Scoreboard, the most current data was collected for each of 9 indicators selected. Most of indicators data was available up to 2011 year.

Following methodology of Innovation Union Scoreboard it was also decided to keep the same grouping of countries: leaders, followers, moderate and modest innovators, when comparing countries according to their Investment to technologies index.

The classification aims to reduce the dimensionality of a data set by exploiting the similarities/dissimilarities between cases [37].

There are many methods of multivariate analysis how 
objects can be grouped to each other. However, recent researches show that cluster analysis is one of the methods that fit well for the classification of different objects: market segments, enterprises, countries, etc. [38]. This method was chosen for the investigation.

\section{RESULTS AND DISCUSSION}

Cluster analysis was performed and it enabled to group countries like is presented in Table I. It is to notice that technological leaders had highest values of summarized ITI index and the values decreased while taking into account technological followers, moderators and modest countries

TABLE I: CLASSIFICATION OF COUNTRIES

\begin{tabular}{|c|c|c|c|c|c|c|c|c|c|c|c|}
\hline \multicolumn{6}{|c|}{ Leaders } & \multicolumn{6}{|c|}{ Followers } \\
\hline Mark & Country & $S K$ & $F I$ & TO & $I T I$ & Mark & Country & $S K$ & $F I$ & $T O$ & $I T I$ \\
\hline$S E$ & Sweden & 0,77 & 0,87 & 0,19 & 1,83 & $D E$ & Germany & 0,50 & 0,65 & 0,50 & 1,64 \\
\hline \multirow[t]{8}{*}{$F I$} & Finland & 0,76 & 0,89 & 0,13 & 1,77 & $U K$ & United Kingdom & 0,59 & 0,42 & 0,49 & 1,50 \\
\hline & & & & & & $F R$ & France & 0,54 & 0,54 & 0,40 & 1,49 \\
\hline & & & & & & $D K$ & Denmark & 0,61 & 0,72 & 0,09 & 1,42 \\
\hline & & & & & & $N L$ & Netherlands & 0,60 & 0,54 & 0,22 & 1,36 \\
\hline & & & & & & $A T$ & Austria & 0,54 & 0,62 & 0,10 & 1,26 \\
\hline & & & & & & $B E$ & Belgium & 0,59 & 0,44 & 0,09 & 1,12 \\
\hline & & & & & & $I E$ & Ireland & 0,60 & 0,30 & 0,13 & 1,03 \\
\hline & & & & & & $S L$ & Slovenia & 0,52 & 0,38 & 0,03 & 0,93 \\
\hline \multicolumn{6}{|c|}{ Moderate countries } & \multicolumn{6}{|c|}{ Modest countries } \\
\hline Mark & Country & SK & FI & TO & ITI & Mark & Country & SK & FI & TO & ITI \\
\hline$I T$ & Italy & 0,33 & 0,28 & 0,32 & 0,93 & $P L$ & Poland & 0,41 & 0,16 & 0,12 & 0,68 \\
\hline$L X$ & Luxembourg & 0,47 & 0,29 & 0,14 & 0,90 & $C Y$ & Cyprus & 0,48 & 0,07 & 0,08 & 0,63 \\
\hline$C Z$ & Czech Republic & 0,40 & 0,34 & 0,14 & 0,88 & $E L$ & Greece & 0,41 & 0,14 & 0,04 & 0,59 \\
\hline$E S$ & Spain & 0,39 & 0,31 & 0,12 & 0,83 & $S K$ & Slovakia & 0,43 & 0,09 & 0,03 & 0,54 \\
\hline$E E$ & Estonia & 0,45 & 0,31 & 0,04 & 0,80 & $M T$ & Malta & 0,15 & 0,08 & 0,31 & 0,54 \\
\hline$H U$ & Hungary & 0,36 & 0,24 & 0,18 & 0,78 & $B G$ & Bulgaria & 0,33 & 0,10 & 0,02 & 0,45 \\
\hline$L T$ & Lithuania & 0,45 & 0,23 & 0,02 & 0,70 & $L V$ & Latvia & 0,31 & 0,12 & 0,02 & 0,45 \\
\hline$P T$ & Portugal & 0,34 & 0,27 & 0,06 & 0,67 & $R O$ & Romania & 0,28 & 0,07 & 0,05 & 0,39 \\
\hline$H R$ & Croatia & 0,39 & 0,22 & 0,03 & 0,64 & & & & & & \\
\hline
\end{tabular}

Comparison of each country in perspectives of financial investment, skills and knowledge and technological output approves reliability of cluster analysis results. There also can be defined some smaller classes of countries having more or less similar position for investment to technologies. For example, Finland and Sweden have the highest results taking into account all indexes, so it is to consider that their keep very similar position. It is to notice that Lithuania is having much more better results in skills and knowledge, while comparing with Financial Investments and especially Technological Output. Going into deeper analysis, the comparison of all 9 indicators was performed and the results are presented in Fig. 1.

The analysis has approved that Lithuania is rather rich in human capital, however it is not able to use having resources in an efficient way. It is evident that in Lithuania education level is high - the values of X2 and X3 indicators are above the average of the group of moderate countries and even above the average of all European Union countries. We have different situation while taking into account the number of new doctorate graduates (X1). This indicator is lower than EU either as moderate countries average. Lithuania is near the average of moderators group as well as the average of EU countries while speaking about public $R \& D$ expenditures. However business expenditure on R\&D is extremely low.

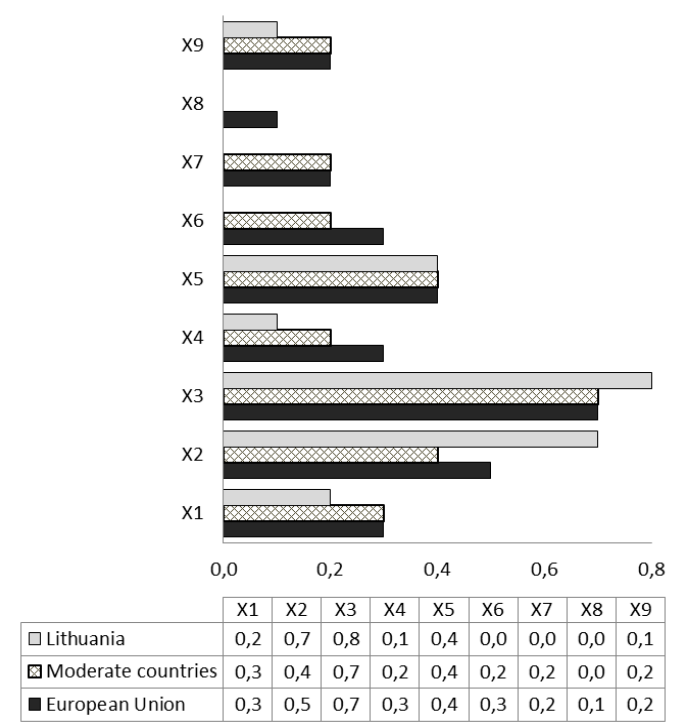

Fig. 1. Comparison of indicators for different countries.

Going further, the main problem is concerned to technological output - Lithuania has extremely small amounts of enterprises performing in high-tech sector, high-tech patent applications and high-tech exports. 
The investigation has shown the main strengths and weaknesses of Lithuania while comparing to other European countries. It is to conclude that human capital is the main strength Lithuania has. These well educated people can play a critical role while creating and adopting high technologies in the market. However, scientist carer is not as attractive as it should be to intake more young people with excellent ideas to R\&D.

The main points that must be developed in Lithuania in order to compete in the global market should also be discussed. First of all Lithuania invests to science but these investments in many cases are not coming back as high value added products or processes. Even if these products are created they are not commercialized in a proper way. So Lithuania has very low Technological Output.

Secondly, there should be strong cooperation between science and business to make sure, that scientific created products are really useful for business or social needs. Government should be also included in this cooperation and its task is to create conditions for high - tech products and processes to be created and developed. The other way to develop technological output is to encourage business to invest to $\mathrm{R} \& \mathrm{D}$, to take the risk of fail and try the innovative ideas.

Coming back to innovation strategy 2010-2020 of Lithuania [4], it is to conclude, that the whole complex of the instruments and activities shall be implemented in order to achieve the main goals of this strategy.

\section{REFERENCES}

[1] C. Freeman and L. Soete, "The economics of industrial innovation," London-Washington: Pinter, 2001.

[2] EC: Europe 2020. A strategy for smart, sustainable and inclusive growth. [Online]. Available: http://eur-lex.europa.eu/LexUriServ/LexUriServ.do?uri=COM:2010:2 020:FIN:EN:PDF

[3] E. Gimzauskiene and L. Valanciene, “ Entrepreneurship education using business simulation models: Cross-functional and cross-disciplinary approaches," in Proc. 2nd International Conference on Economic, Education and Managament, ICEEM 2012, Shanghai, China, June 1-2, 2012, pp. 314-320.

[4] Lithuanian Innovation Strategy 2010-2020 (in Lithuanian) (February 2010). [Online]. Available: http://www3.lrs.lt/pls/inter3/dokpaieska.showdoc_1?p_id=365849

[5] R. M. Solow, "Contribution to the theory of economic growth," Quarterly Journal of Economics, pp. 65-94, 1956.

[6] J. A. Schumpeter, The Theory of Economic Development, Boston: Harvard University Press, 1934.

[7] P. M. Romer, "Endogenous technological change," Journal of Political Economy, vol. 98, no. 5, pp. 71-102, 1990.

[8] G. M. Grossman and E. Helpman, Innovation and Growth in the Global Economy, London: Cambridge (MA), 1991.

[9] J. S. Metacalfe, Evolutionary Economics and Creative Destruction, London: Routledge, 1998.

[10] B. A. Lundvall, Product Innovation and User-Producer Interaction, Aalborg: Aalborg University Press, 1985.

[11] H. Hollanders and S. Tarantola, Innovation Union Scoreboard 2010 -Methodology Report, Joint Research Centre (JRC), Unit G3, January 2011

[12] C. J. Plosser, "The search for growth," in Proc. Policines for Long-Run Economic Growth, WY. Kansas City, MO: Federal Reserve Bank of Kansas City, 1992, pp. 57-86.

[13] R. J. Barro and X. S. Martin, Economic Growth, London: Cambridge (MA), 2004.

[14] P. Aghion and P. Howitt, Endogenous Growth Theory, London: Cambridge (MA), 1998.

[15] E. Helpman, "Endogenous macroeconomic growth theory," in NBER Working Papers Series, Working Paper No. 3869, London: Cambridge (MA), October 1991
[16] A. P. Bartel, "Workplace training in the United States," in Human Capital and Economic Development, S. Aseta, and W. C. Huang (Eds), Kalamazoo, MI: Upjohn Institute for Employment Research, 1994, pp. 109-128.

[17] R. Nelson and S. Winter, "Neoclassical versus evolutionary theories of economic growth: Critique and perspective," Econ. J, pp. 886-905, 1974.

[18] A. Marshal, "Principles of economics," An Introductionary Volume, 9th ed. Reprint, London: Macmillan, 1961.

[19] G. Dosi and R. Nelson, "An introduction to evolutionary theories in economics," J. Evol. Econ., vol. 4, pp. 153-172, 1994

[20] R. J. Sandilands, "Perspectives on Allyn Young in theories of endogenous growth," Journal of the History of Economic Thought, Cambridge University Press, vol. 22, no. 3, pp. 309-328, 2000.

[21] R. Martin and P. Sunley, "Deconstructing clusters: chaotic concept or policy panacea?” J. Economical Geography, vol. 3, no. 1, pp. 5-35, 2003.

[22] W. W. Powell and K. Snellman, "The knowledge economy," Annual Review Sociology, vol. 30, pp. 199-220, 2004.

[23] D. H. C. Chen and C. J. Dahlman, "The knowledge economy: the KAM methodology and world bank operations," World Bank Institute Working Paper No. 37256, 2005.

[24] L. Juozaitienè and A. Čižauskaitè, "Žiniu ekonomika ir jos vystymosi tendencijos Lietuvoje ES šaliu kontekste," Ekonomika ir Vadyba: Aktualijos ir Perspektyvos, in Lithuanian, vol. 2, no. 18, pp. 53-63, 2010.

[25] T. Miller, K. R. Holmes, and E. J. Feulner. (2013). Index of Economic Freedom. Washington, D.C.: The Heritage Foundation and Dow Jones \& Company. Inc. Available: http://www.heritage.org/index.

[26] EC Directorate for Enterprise and Industry: Innovation Union Scoreboard (2013). [Online]. Available: http://ec.europa.eu/enterprise/policies/innovation/facts-figures-analysi s/innovation-scoreboard/index_en.htm

[27] Investing in intangibles: Economic assets and innovation drivers for growth, Analytical Report 2013, Flash Eurobarometer 369.

[28] Innovation in the public sector: Its perception in and impact on business, Analytical Report 2012, Flash Eurobarometer 343.

[29] Comsumer protection and consumer rights, Analytical Report 2009, Flash Eurobarometer 267.

[30] Innovation Transfer, Analytical Report 2007, Flash Eurobarometer 215.

[31] Special target: Companies operating in clusters, Analytical Report 2006, Flash Eurobarometer 187.

[32] R. Evangelista, "Sectoral patterns of technological change in services," Economics of Innovation and New Technology, vol. 9, no. 3, pp. $183-222,2000$

[33] A. Arundel and A. Geuna, "Proximity and the use of public science by innovative European firms," Economics of Innovation and New Technology, vol. 13, no. 6, pp. 559-580, 2004.

[34] H. Lööf and A. Heshmati, "On the relationship between innovation and performance: A sensitivity analysis," Economics of Innovation and New Technology, vol. 15, no. 4-5, pp.317-344, 2006.

[35] A. Yousefi, "The impact of information and communication technology on economic growth: Evidence from developed and developing countries," Economics of Innovation and New Technology, vol. 20 , no. 6 , pp. 581-596, 2011

[36] A. Heshmati and S. C. Kumbhakar. (June, 2013). A general model of technical change with an application to the OECD countries. Economics of Innovation and New Technology. [Online]. Available: http://www.tandfonline.com/doi/abs/10.1080/10438599.2013.805918 \#.UqDeY7CIpy1

[37] R. Bouis and R. Duval. (2011). Economic Policy Reforms 2011: Going for growth. OECD Publishing. [Online]. Available: http://dx.doi.org/10.1787/growth 2011

[38] V. Boguslauskas and R. Adlyte, "Evaluation of criteria for the classification of enterprises," Inzinerine Ekonomika-Engineering Economics, vol. 1, pp. 119-127, 2010.

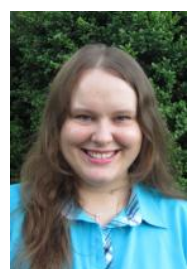

Ruta Adlyte is currently a Ph.D. candidate at Kaunas University of Technology, Lithuania. Her thesis is related to investment to technologies, its relations to external and internal business factors evaluation. Ruta is also an assistant professor at Accounting Department. Her research interest covers evaluation of economic indicators, statistical and econometrical analysis. 
Loreta Valanciene has obtained her Ph.D. in Management and administration at Kaunas University of Technology (Lithuania) and has been working with the same institution for more than 15 years. Now she is a professor and head of Accounting Department. She is currently lecturing Value based management, Business analysis and valuation courses. Her research interest covers management accounting, value measurement system, relationship between external and internal environmental factors of organization and economic indicators.

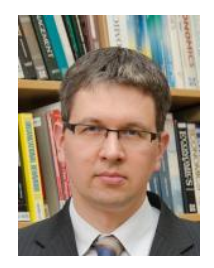

Rytis Krusinskas is a professor, and head of the Department of Finance in Kaunas University of Technology, Economics and Business Faculty. He is also head of Institutional Economic Research Program for 2012 - 2014 "Lithuania Economy Sustainable Competitiveness Challenges" funded by The Research Council of Lithuania. He was born in Kaunas, Lithuania in 1977. He holds bachelor degree in Mechanical Engineering (1999, Production and business systems for SMEs), master of science degree in Industrial Engineering and Management (2001, International Master Studies of BALTECH Consortium) and $\mathrm{PhD}$ in Social Sciences (2008, Management and Administration). Research interests are in the areas of financial management, technology investment valuation, economic and social effectiveness measurement, cost - benefit analysis, strategic financial management decisions, financial planning and modelling. 